\title{
Corela
}

Cognition, représentation, langage

HS-29 | 2019

Questions et exclamations au prisme de plusieurs approches linguistiques

\section{Corpus : Questions \\ Texte Agatha Christie}

\section{OpenEdition}

Journals

Édition électronique

URL : http://journals.openedition.org/corela/8572

DOI : $10.4000 /$ corela. 8572

ISSN : $1638-573 \mathrm{X}$

Éditeur

Cercle linguistique du Centre et de l'Ouest - CerLICO

Référence électronique

"Corpus : Questions

Texte Agatha Christie », Corela [En ligne], HS-29 | 2019, mis en ligne le 05 septembre 2019, consulté le 28 octobre 2019. URL : http://journals.openedition.org/corela/8572 ; DOI : 10.4000/corela.8572

Ce document a été généré automatiquement le 28 octobre 2019.

Corela - cognition, représentation, langage est mis à disposition selon les termes de la licence Creative Commons Attribution - Pas d'Utilisation Commerciale - Partage dans les Mêmes Conditions 4.0 International. 


\section{Corpus : Questions Texte Agatha Christie}

1 So - on to the 'next thing, Madam.' The change in George! Iris couldn't put it off any longer. When had that begun? What was the cause of it?

2 Even now, thinking back, Iris could not put her finger definitely on the moment when it began. Ever since Rosemary's death George had been abstracted, had had fits of inattention and brooding. He had seemed older, heavier. That was all natural enough. But when exactly had his abstraction become something more than natural?

3 It was, she thought, after their clash over Anthony Browne, that she had first noticed him staring at her in a bemused, perplexed manner. Then he formed a new habit of coming home early from business and shutting himself up in his study. He didn't seem to be doing anything there. She had gone in once and found him sitting at his desk staring straight ahead of him. He looked at her when she came in with dull lack-lustre eyes. He behaved like a man who has had a shock, but to her question as to what was the matter, he replied briefly, 'Nothing.'

4 As the days went on, he went about with the careworn look of a man who has some definite worry upon his mind.

5 Nobody had paid very much attention. Iris certainly hadn't. Worries were always conveniently 'business.'

6 Then, at odd intervals, and with no seeming reason, he began to ask questions. It was then that she began to put his manner down as definitely 'queer.'

7 'Look here, Iris, did Rosemary ever talk to you much?'

8 Iris stared at him.

9 'Why, of course, George. At least - well, about what?'

10 'Oh, herself - her friends - how things were going with her. Whether she was happy or unhappy. That sort of thing.'

11 She thought she saw what was in his mind. He must have got wind of Rosemary's unhappy love affair.

12 She said slowly: 'She never said much. I mean - she was always busy - doing things.' 
'And you were only a kid, of course. Yes, I know. All the same, I thought she might have said something.'

He looked at her inquiringly - rather like a hopeful dog.

She didn't want George to be hurt. And anyway Rosemary never had said anything.

She shook her head.

George sighed. He said heavily: 'Oh, well, it doesn't matter.'

Another day he asked her suddenly who Rosemary's best women friends had been.

Iris reflected.

'Gloria King. Mrs Atwell - Maisie Atwell. Jean Raymond.'

'How intimate was she with them?'

'Well, I don't know exactly.'

'I mean, do you think she might have confided in any of them?'

'I don't really know... I don't think it's awfully likely... What sort of confidence do you mean?'

Immediately she wished she hadn't asked that last question, but George's response to it surprised her.

'Did Rosemary ever say she was afraid of anybody?'

'Afraid?' Iris stared.

'What I'm trying to get at is, did Rosemary have any enemies?'

'Amongst other women?'

'No, no, not that kind of thing. Real enemies. There wasn't anyone - that you knew of who - who might have had it in for her?'

Iris's frank stare seemed to upset him. He reddened, muttered:

'Sounds silly, I know. Melodramatic, but I just wondered.'

It was a day or two after that that he started asking about the Farradays.

How much had Rosemary seen of the Farradays?

Iris was doubtful.

'I really don't know, George.'

'Did she ever talk about them?'

'No, I don't think so.'

'Were they intimate at all?'

'Rosemary was very interested in politics.'

'Yes. After she met the Farradays in Switzerland. Never cared a button about politics before that.'

'No. I think Stephen Farraday interested her in them. He used to lend her pamphlets and things.'

George said: 'What did Sandra Farraday think about it?'

'About what?'

'About her husband lending Rosemary pamphlets.' 

The round table at the Luxembourg, the shaded lights, the flowers. The dance band with its insistent rhythm. The seven people round the table, herself, Anthony Browne, Rosemary, Stephen Farraday, Ruth Lessing, George, and on George's right, Stephen Farraday's wife, Lady Alexandra Farraday with her pale straight hair and those slightly arched nostrils and her clear arrogant voice. Such a gay party it had been, or hadn't it?

Iris said uncomfortably: 'I don't know.'

George said, 'She's a very reserved woman. Looks cold as ice. But they say she's crazy about Farraday. Sort of woman who might resent his having a friendship with another woman.'

'Perhaps.'

'How did Rosemary and Farraday's wife get on?'

Iris said slowly: 'I don't think they did. Rosemary laughed at Sandra. Said she was one of those stuffed political women like a rocking horse. (She is rather like a horse, you know.) Rosemary used to say that "if you pricked her sawdust would ooze out."

George grunted. Then he said: 'Still seeing a good deal of Anthony Browne?'

'A fair amount.' Iris's voice was cold, but George did not repeat his warnings. Instead he seemed interested.

'Knocked about a good deal, hasn't he? Must have had an interesting life. Does he ever talk to you about it?'

'Not much. He's travelled a lot, of course.'

'Business, I suppose.'

'I suppose so.'

'What is his business?'

'I don't know.'

'Something to do with armament firms, isn't it?'

'He's never said.'

'Well, needn't mention I asked. I just wondered. He was about a lot last Autumn with Dewsbury, who's chairman of the United Arms Ltd... Rosemary saw rather a lot of Anthony Browne, didn't she?'

'Yes - yes, she did.'

'But she hadn't known him very long - he was more or less of a casual acquaintance? Used to take her dancing, didn't he?'

'Yes.'

'I was rather surprised, you know, that she wanted him at her birthday party. Didn't realise she knew him so well.'

Iris said quietly: 'He dances very well...'

'Yes - yes, of course...'

Without wishing to, Iris unwillingly let a picture of that evening flit across her mind.

A. Christie, Sparkling Cyanide (1945). PerfectBound / HarperCollins: 32-37 